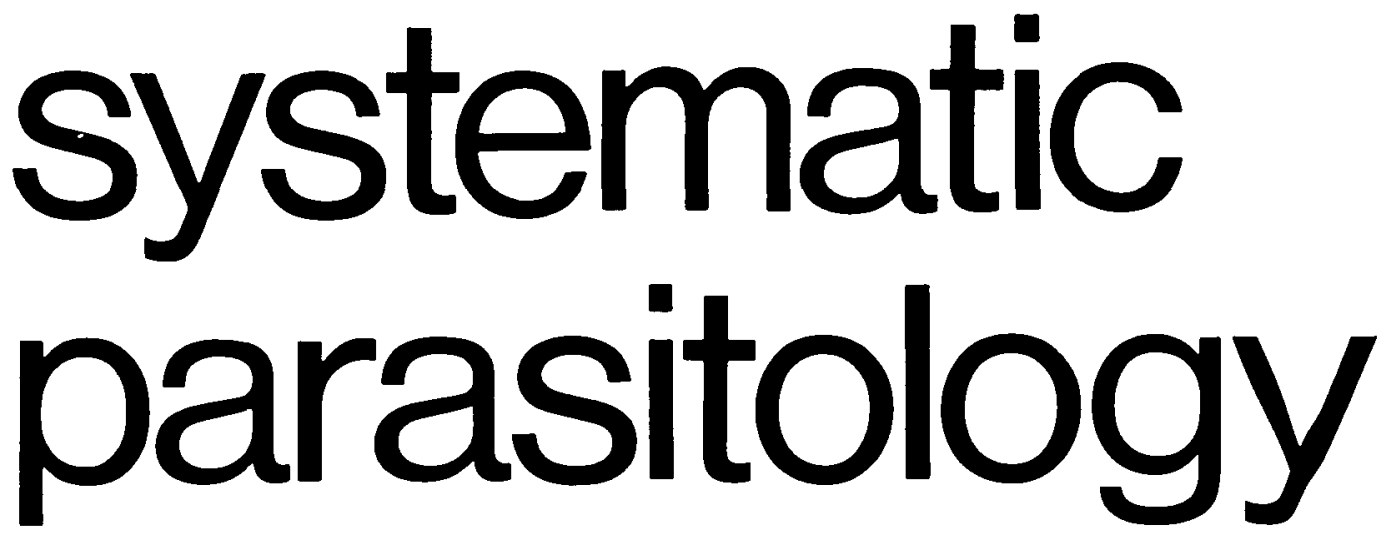

editor In chlef

Or. Sheila Willmott

Commonwealth Institute of

Heiminthology

St. Albans England co editore

R. C. Anderson (Canada)

J. R. Baker (England)

I. Beveridge (Australia)

A. G. Chabaud (France)

L. Euzet (France)
M, T. Franklin (England)

Z. Kabata (Canada)

J. J. Laarman (The Netherlands)

J. C. Pearson (Australia)

G. D. Schmidt (USA)

This new journal is being produced as a direct response to the increasing recognition of the fundamental importance of sound systematics in biology, especially as applied to those parasitic organisms which affect the health of man, animals and plants throughout the world.

In scope, it will cover Nemathelminthes (including plant parasites), Platyhelminthes, parasitic Arthropoda and Protozoa, and parasitic genera in other invertebrate groups.

The highest scientific standards of work will be required and descriptions of new taxa will not normally be accepted unless specimens are made available for scrutiny by the referees.

Initially, the journal will be issued quarterly, the first part to appear early in 1979. Papers, brief communications and research notes describing original work and major revisions of a high standard will be acceptable for publication. It is the aim to publish within six months of acceptance.

\title{
Subscription information.
}

The subscription price for volume 1 (4 issues), 1979, is Dfl. 120,00 plus Dfl. 18,50 for postage and handling.

Private subscribers are entitled to a $50 \%$ discount on the subscription price (i.e. Dfl. 60,00 plus Dfl. 18,50 for postage and handling).

Orders should be sent to our distribution centre: Kluwer Academic Publishers Group, P.O. Box 322, 3300 AH Dordrecht, The Netherlands.

Parasitology, 78, 3 


\section{PARASITOLOGY}




\section{PARASITOLOGY}

(Founded by G.H.F. Nuttall, F.R.S.)

EDITORS

D. W. T. CROMPTON and B. A. NEWTON

EDITORIAL ASSISTANT

M. ELISABETH PAINTER, Ph.D.

ADVISORY BOARD

GWENDOLEN REES, F.R.S. (Chairman)
R. ANDERSON
D. I. GIBSON
J. H. ROSE
D. R. ARTHUR
L. G. GOODWIN, E.R.S.
J. F. RYLEY
J. R. BAKER
L. P. JOYNER
G. SALT, F.R.S.
J. BARRETT
C. R. KENNEDY
S. R. SMITHERS
ELIZABETH U. CANNING
ANN M. LACKIE
K. VICKERMAN
L. H. CHAPPELL
D. L. LEE*
D. WAKELIN
S. COHEN
R. J. LINCOLN
P. F. V. WARD
R. R. A. COOMBS, F.R.S.
J. LLEWELLYN
P. J. WHITFIELD
F. E. G. COX
S. H. P. MADDREL L
H. H. WILLIAM S
G. A. M. CROSS
BRIDGET M. OGILVIE
R. A. WILSON
D. A. ERASMUS
M. ELAINE ROSE
C. A. WRIGHT

* Representing the British Society for Parasitology

V OLUME 78,1979

CAMBRIDGE UNIVERSITY PRESS

CAMBRIDGE - LONDON - NEW YORK 


\section{PUBLISHED BY}

THE SYNDICS OF THE CAMBRIDGE UNIVERSITY PRESS

The Pitt Building, Trumpington Street, Cambridge CB2 1RP

Bentley House, 200 Euston Road, London NW1 2DB

32 East 57th Street, Now York, N.Y. 10022

(C) Cambridge University Press, 1979 


\section{CONTENTS}

\section{(All rights reserved)}

\section{Part 1 February 1979}

PAGE

Morexo, M. Sanchez and Barrett, J. Monoamine oxidase in adult Hymenolepis diminuta (Cestoda) . . . . . . . . . . . 1

Healy, J. A. Phosphoglucomutase polymorphism in the tick Ixodes ricinus

SCHILdknecht, E. G. and SquibB, R. L. The effect of vitamins A, E and K on experimentally induced histomoniasis in turkeys . . . .

Panitz, E. Efficacy and cross-resistance studies on $N, N^{\prime}$-bis $(3,4$ ditrifluoromethylphenyl) methylmalonamide, a novel anticoccidial agent .

Long, P. L. and Mrlcard, B. J. Studies on Eimeria dispersa Tyzzer 1929 in turkeys

RILEY, J., JAMES, J. L. and BanaJA, A. A. The possible role of the frontal and subparietal gland systems of the pentastomid Reighardia sternae (Diesing, 1864) in the evasion of the host immune response .

Langhorne, J. and Cohen, W. Plasmodium knowlesi in the marmoset (Callithrix jacchus) .

Bomford, R. and McHARDY, N. Corynebacterium parvum as an adjuvant for Trypanosoma cruzi epimastigote vaccines : a comparison with saponin and Bordetella pertussis . . . . . . . . . . . .

Kipnis, T. L., Calich, V. L. G. and Dras da Sinva, W. Active entry of bloodstream forms of Trypanosoma cruzi into macrophages . . .

Hragins, J.C. The role of the tegument of the metacercarial stage of Bucephalus haimeanus (Lacaze-Duthiers, 1854) in the absorption of particulate material and small molecules in solution

\section{PART 2 APRIL 1979}

Le Jambre, L. F., Royal, W. M. and Martin, P. J. The inheritance of thiabendazole resistance in Haemonchus contortus . . . . .

Kennedy, M. W., Wakelin, D. and Winson, Margaret M. Transplantation of adult Trichinella spiralis between hosts: worm survival and immunological characteristics of the host-parasite relationship . .

Wharton, D. A. Oogenesis and egg-shell formation in Aspiculuris tetraptera Schulz (Nematoda: Oxyuroidea) . . . . . . . . .

Wharton, D. A. The structure of the egg-shell of Aspiculuris tetraptera Schulz (Nematoda: Oxyuroidea) . . . . . . . . . 
Higby, G. C., Canning, Elizabeth U., Pilley, Barbara M. and Bush, P. J. Propagation of Nosema eurytremae (Microsporida: Nosematidae) from trematode larvae, in abnormal hosts and in tissue culture .

DoENhoFf, M. and LoNG, E. Factors affecting the acquisition of resistance against Schistosoma mansoni in the mouse. IV. The inability of T-celldeprived mice to resist re-infection, and other in vivo studies on the mechanisms of resistance

Bickle, Q. D., Taylor, M. G., James, E. R., Nelson, G. S., Hussen, M. F., Andrews, B. J., Dobinson, A. R. and Marshall, T. F. DE C. Further observations on immunization of sheep against Schistosoma mansoni and $S$. bovis using irradiation-attenuated schistosomula of homologous and heterologous species . . . . . . . .

Boxrucker, J. C. Effects of a thermal effluent on the incidence and abundance of the gill and intestinal metazoan parasites of the black bullhead

Sherlock, P. L. Diplocystis tipulae sp.nov. (Sporozoa: Eugregarinorida), a parasite of Tipula paludosa Meigen (Diptera: Tipulidae) . . .

ShIRLEY, M. W. A reappraisal of the taxonomic status of Eimeria mivati Edgar and Seibold 1964, by enzyme electrophoresis and cross-immunity tests

Long, P. L. and MmlaRd, B. J. Rejection of Eimeria by foreign hosts .

\section{Part 3 June 1979}

DoJiri, Masahiro. Two new species of Lepeophtheirus (Copepoda: Caligidae) parasitic on fishes from southern California waters

Howard, R. J. and BatTye, F. L. Plasmodium berghei-infected red cells sorted according to DNA content . . . . . . . . .

Dargie, J. D., Murray, P. K., Murray, Max, Grimshaw, W. R. T. and McIntyRe, W. I. M. Bovine trypanosomiasis: the red cell kinetics of Ndama and Zebu cattle infected with Trypanosoma congolense . .

Watts, S. D. M., OrPIN, A. and MacCormick, C. Lysosomes and tegument pathology in the chemotherapy of schistosomiasis with 1,7-bis(paminophenoxy)heptane (153C51) . . . . . . . .

WIISON, R. A. and BARNeS, P. E. Synthesis of macromolecules by the epithelial surfaces of Schistosoma mansoni: an autoradiographic study

Smrth, M. A. and Clegg, J. A. Different levels of immunity to Schistosoma mansoni in the mouse: the role of variant cercariae 
Christie, P. R., WAkELIN, D. and WILson, M. M. The effect of the expulsion phase of Trichinella spiralis on Hymenolepis diminuta infection in rats

Borgsteede, F. H. M. and Hendriks, J. Experimental infections with Cooperia oncophora (Railliet, 1918) in calves. Results of single infections with two graded dose levels of larvae

Chen, S. N. and Howells, R. E. The uptake in vitro of dyes, monosaccharides and amino acids by the filarial worm Brugia pahangi .

Premvatr, G. and Chopra, AshoK K. In vitro variation of glycogen content in three sheep nematodes

Rollinson, D., Joyner, L. P. and Norton, C. C. Eimeria maxima: the use of enzyme markers to detect the genetic transfer of drug resistance between lines. 


\section{PARASITOLOGY}

SUBSCRIPTIONS may be sent to any bookseller or subscription agent or direct to Cambridge University Press, P.O. Box 110, Cambridge CB2 3RL. Subscriptions in the U.S.A. and Canada should be sent to Cambridge University Press, 32 East 57th Street, New York, N.Y. 10022. The subscription price of volumes 78 and 79, 1979, is $£ 21.00$ net (including postage) for a volume of three parts (US $\$ 52.50$ in the U.S.A. and Canada) payable in advance ( $\$ 42.00$ or US $\$ 105.00$ per year); separate parts cost $£ 9.00$ net or US $\$ 22.50$ each (plus postage).

BACK VOLUMEs. Vols. 1-39: Inquiries should be addressed to Wm. Dawson \& Sons Ltd, Cannon House, Folkestone, Kent. Vols. 40 onwards: quotations for parts still in print may be obtained from the Cambridge or New York offices of the Cambridge University Press.

COPYING. This journal is registered with the Copyright Clearance Center, New York. Organizations in the U.S.A. who are also registered with C.C.C. may therefore copy material (beyond the limits permitted by sections 107 and 108 of U.S. (c) law) subject to payment to C.C.C. of the per-copy fee indicated in the code on the first page of the article. This consent does not extend to multiple copying for promotional or commercial purposes.

ISI tear Service, 325 Chestnut Street, Philadelphia, Pennsylvania 19106, U.S.A., is authorized to supply single copies of separate articles for private use only.

FOR ALL OTHER USE, permission should be sought from the Cambridge or New York offices of the Cambridge University Press.

CLAIMs for missing issues can only be considered if made immediately after receipt of the subsequent issue.

ADvertising. Details of advertising in Parasitology may be obtained from the publisher. 


\section{PARASITOLOGY}

Volume 78, Part 3, June 1979

\section{GONTENTS}

DoJiri, Masariro. Two new species of Lepeophtheirus (Copepoda; Caligidae) parasitic on fishes from southern California waters

PAGE

Howard, R.J. and Battye, F. L. Plasmodium berghei-infected red cells sorted according to DNA content

Dargie, J. D., Murray, P. K., Murray, Max, Grimshaw, W. R. T. and McIntyre, W. I. M. Bovine trypanosomiasis: the red cell kinetics of Ndama and Zebu cattle infected with Trypanosoma congolense

WATrs, S. D. M., OrPin, A. and MACCormoK, C. Lysosomes and tegument pathology in the chemotherapy of schistosomiasis with 1,7-bis( $p$-aminophenoxy)heptane (153C51)

Wilson, R. A. and Barnes, P. E. Synthesis of macromolecules by the epithelial surfaces of Schistosoma mansoni: an autoradiographic study

Smith, M. A. and Clegg, J. A. Different levels of immunity to Schistosoma mansoni in the mouse: the role of variant cercariae

Christie, P. R., WAKELIN, D. and Wrison, M. M. The effect of the expulsion phase of Trichinella spiralis on Hymenolepis diminuta infection in rats

Bongstemde, F.H.M. and Hendrms, J. Experimental infections with Cooperia oncophora (Railliet, 1918) in calves. Results of single infections with two graded dose levels of larvae

Chen, S. N. and HoweuLs, R. E. The uptake in vitro of dyes, monosaccharides and amino acids by the filarial worm Brugia pahangi

Premvati, G. and Chopra, AshoK K. In vitro variation of glycogen content in three sheep nematodes

Rollinson, D., Joyner, L. P. and Norton, C. C. Eimeria maxima: the use of enzyme markers to detect the genetic transfer of drug resistance between lines

The Pitt Building, Trumpington Street, Cambridge CB2 1RP

Bentley House, 200 Euston Road, London NW1 2DB

32 East 57th Street, New York, N.Y. 10022

Printed in Great Britain at the University Press, Cambridge 